\title{
The International Monetary Fund: A review of the recent evidence
}

\author{
Martin C. Steinwand • Randall W. Stone
}

Received: 16 November 2006 / Revised: 7 June 2007 / Accepted: 30 July 2007 /

Published online: 4 March 2008

(C) Springer Science + Business Media, LLC 2007

\begin{abstract}
A review of recent quantitative studies on the International Monetary Fund reveals that much of the conventional wisdom is incorrect. Recent studies have demonstrated a new degree of methodological rigor, have drawn more heavily upon insights from political science, and have asked a number of new questions. We review studies of participation in IMF programs, design of IMF conditionality, implementation and enforcement of IMF conditions, conventional program effects and catalytic effects. At every stage, we find substantial evidence of the influence of major IMF shareholders, of the Fund's own organizational imperatives, and of domestic politics within borrowing countries. We conclude that very little is known with certainty about the effects of IMF lending, but that a great deal has been learned about the mechanics of IMF programs that will have to be taken into account in order to obtain unbiased estimates of those effects.
\end{abstract}

Keywords IMF. Survey· Quantitative studies

JEL codes $\mathrm{F} 33 \cdot \mathrm{F} 34 \cdot \mathrm{F} 35$

The last two decades have witnessed a profound acceleration of international transactions. The collapse of Communism and the increased salience of global capital flows propelled the International Monetary Fund (IMF, or the Fund) to undertake much wider and more profound interventions in global domestic politics. By the mid-1990s it was possible to speak of a "Washington Consensus," a set of policies leading to liberalized trade and financial flows, privatization, and deregulation that were embraced by the advanced industrial countries, promoted by the Fund in cooperation with other international financial and trade institutions, and increasingly implemented in the developing world (Williamson 1997). This consensus is now widely criticized in the aftermath of the Asian financial crisis of

M. C. Steinwand $\cdot$ R. W. Stone $(\bowtie)$

University of Rochester, Rochester, NY, USA

e-mail: randall.stone@rochester.edu 
1997. Latin American incomes stagnated long after the Asian crisis, and African incomes have not improved since the early 1980s, despite extensive IMF lending. Global inequality is on the rise.

The diagnoses are as varied as the critics. On one hand, the Fund is criticized for promoting moral hazard and dependency (Goldstein 2001, Hills et al. 1999). On the other, it is accused of imposing uniform policy reforms that do not correspond to local conditions and promoting the interests of investors and powerful developed countries rather than of borrowers (e.g., Meltzer 2000, Easterly 2001, and Stiglitz 2002). Studies conducted by the IMF's Independent Evaluation Office have been critical of the Fund's response to major crises, and the debate has been echoed in the pages of this journal (IEO 2003a, b, 2004, Meltzer 2006, Krueger 2006). A long tradition of quantitative studies has mixed and inconclusive findings, but generally casts doubt on arguments that the IMF has strong effects, either positive or negative. Developments in the last five years, however, have led to new questions, the use of new methods, and the discovery of important new findings. It is time for a reassessment of the state of quantitative literature on the IMF. ${ }^{1}$

The recent contributions to the literature innovate on three dimensions. First, they introduce more sophisticated methods of statistical analysis to correct for the selection problems that had plagued the previous generation of studies. Recent studies have overturned previous findings and provided a firmer empirical basis for generalization. Second, recent studies have moved beyond the traditional focus on the policy effects of IMF programs to investigate new questions: Which countries participate in IMF programs? What conditions are they required to fulfill? To what degree are IMF programs implemented, and if the conditions are not met, are they enforced? Do IMF programs have catalytic effects that promote private capital flows? New questions have led to new findings. Third, recent empirical studies have made explicit connections with theoretical debates in political science, putting an end to the isolation of IMF studies from the broader study of international institutions. As a result, a pattern of findings is beginning to emerge that casts new light on the conditions under which IMF intervention can be expected to have positive or negative effects.

\section{New Directions}

Selection is the fundamental methodological problem in studies of the IMF, and addressing it adequately requires theoretical progress. Assessments of the effects of IMF intervention were traditionally based on before-after or with-without comparisons, which treated countries with IMF programs as the treatment group and countries without as the control group. This approach neglected the fact that the two sample populations differed in important ways because countries' decisions to

\footnotetext{
${ }^{1}$ The most comprehensive review of the quantitative literature to 2000 is in Stone (2002). Instead of recapitulating those themes, the present essay focuses on subsequent developments. Two useful reviews of literature on the IMF that partially overlap with the studies we cover have appeared, Bird (2007) and Joyce (2004). The present paper more systematically covers the quantitative studies, but only the quantitative ones, and distinguishes itself by focusing explicitly on important new methodological and theoretical developments.
} 
participate in IMF programs and the IMF's decisions to extend programs were not random. For example, if countries that are vulnerable to financial crises are more likely to participate in IMF programs, failing to correct selection bias could lead to the erroneous conclusion that IMF programs cause these crises. Alternatively, if the IMF is more willing to extend financing to governments with sound fiscal policies, uncorrected studies could exaggerate the IMF's effectiveness at promoting fiscal probity. These problems were widely recognized long before they were adequately addressed (Goldstein and Montiel 1986). A distinctive feature of the new literature on the IMF-which is now almost universal, and is rapidly becoming a necessary condition for publication - is that it systematically addresses selection. ${ }^{2}$

The new literature on the IMF opens a number of new substantive questions for discussion. First, the methodological concern with selection has focused attention on explaining IMF program participation. The estimation strategies employed are gradually evolving from economic forecasting models to theoretically driven political-economy models that incorporate domestic politics and international strategic factors. As we will see below, these studies are uncovering uncomfortable facts about how the institution functions. Second, the normative concern with the welfare effects of IMF programs has led to conflicting diagnoses: when IMF programs are ineffective, is this because they are poorly designed, or because they are poorly implemented? The first suspicion suggests the need for studies of IMF conditionality, which have only recently become feasible because the IMF has made its archives and its data more readily available to researchers. The second hypothesis implies the need to study the implementation of IMF programs. Finally, a key claim of the IMF is that, although the volume of its lending is relatively modest, its resources are supplemented by private capital flows because the IMF's approval of a country's policies acts as a seal of approval that reassures investors. If this were not true, the argument for adopting IMF-promoted austerity programs would be weak, and the sanctions available to the IMF would be ineffective. Assessing the empirical evidence for this claim leads to studies of the catalytic effects of IMF programs.

Statistical models are only as good as the theories that motivate them, and studies of the IMF have become more self-consciously theoretical in recent years. Theoretical expectations about the effects of international institutions depend on assumptions about what functions they serve, and for whom. The theories that have been prominent in international political economy fall into three main categories: functionalist, structural, and public choice. Functionalist views focus on common interests in cooperation and rely on transaction costs to explain institutions; structural ones expect conflict and use power to explain institutions; public choice approaches look for rent seeking and expect principal-agent relationships to explain institutions. ${ }^{3}$

\footnotetext{
${ }^{2}$ The first wave of studies to address this issue used the Generalized Estimation Estimator (GEE), which has subsequently fallen out of favor because it does not address selection bias caused by unobservable variables. Hutchison (2003) compares the GEE favorably to a Heckman selection model, but might find the Heckman model more efficient if political variables were included in the selection equation.

${ }^{3}$ We deliberately avoid referring to the messy concepts of "realism" and "neoliberalism" because they are too poorly specified to be very useful, and they carry with them a great deal of baggage. In addition, the three perspectives outlined here do not map neatly onto the debates in international relations: structural models, for example, may be Marxist rather than realist.
} 
An accurate description of institutional design would touch on all three perspectives, but here the task is to sharpen the differences among them. Each perspective finds expression - and some empirical support—in recent work on the IMF.

The functionalist perspective, which is the one most widely adopted in the IMF literature, emphasizes the element of common interest in cooperation (Keohane 1984). Institutions, in this perspective, arise as solutions to collective action problems, or political market failures, where common interests would otherwise be unattainable because of excessive transaction costs. The details of institutional design are attributable to the characteristics of the transaction costs - search, bargaining, and enforcement problems - particular to the kind of cooperation they were designed to promote (Koremenos et al. 2004). Institutions are welfare enhancing for their members, although they may reduce the welfare of non-members (Oye 1992). If they have harmful attributes, these arise as unintended consequences of their positive activities. For example, the existence of the IMF as a lender of last resort may generate moral hazard. ${ }^{4}$ International institutions are underprovided, however, because creating them requires countries to overcome collective action problems. International cooperation usually requires asymmetric contributions by the most powerful states in the system, because they benefit most from cooperation and have the greatest incentives to try to round up free riders.

In contrast, the structural approach emphasizes differences in national interests and the distribution of power (Krasner 1985). Structural explanations treat the existence of conflicts of interest as fundamental, although the particular reasons for conflict vary with the international context. Krasner, for example, argued that the fundamental structural conflict was between rich countries with strong states that expected to benefit from expanding trade and financial flows, and poor countries with weak states that found themselves exposed to all of their risks. International institutions and their rules are the creations of powerful states, and they reflect their preferences, so they will frequently harm the interests of smaller countries and weaker states. Following along these lines, recent studies have asked whether the distribution of IMF loans, the bargaining over conditionality, or the enforcement of IMF performance criteria reflected the priorities and interference of the leading states in the international system. When international institutions fail to serve their ostensible functions, structural explanations point to the role powerful states had in making the rules, and the interests they have in making exceptions to them.

\footnotetext{
${ }^{4}$ E.g., Goldstein (1998). Recent theoretical work on the problem of moral hazard illustrates the functionalist logic. Powell and Arozamena (2003) argue that the IMF has to keep financial markets guessing in order to minimize moral hazard. In their formal model, the IMF provides protection against liquidity crises, but its lender-of-last resort function generates moral hazard. Consequently, the IMF has to play a mixed strategy — refusing to provide a financial bail-out with some probability - in order to ensure the borrowing country's cooperation. Cooperation between the IMF and the borrowing country is feasible as long as the probability of default is tolerably low; however, the target country defects once the probability of insolvency becomes sufficiently high. On the other hand, Plaut and Melnik (2003) argue that the choice of long-term over short-term lending is an adaptation to minimize moral hazard. Long-term IMF lending is Pareto superior to short-term emergency lending, in their model, because the target country and financial markets face less uncertainty about the future levels and conditions of IMF lending. This minimizes moral hazard because it imposes a maximum level on the financing that countries can expect. 
The public choice framework (Vaubel 1986, 1996) emphasizes the perverse incentives created by principal-agent relationships under incomplete information. The objectives of international bureaucrats are to increase their power, perquisites and organizational slack, and elected officials delegate authority to them in order to escape from their own accountability to voters. It is often argued that the IMF is able to provide political cover for governments that want to reform their economies but face opposition at home (Putnam 1988; Haggard and Kaufman 1995; Vreeland 2003). In each of these arguments, governments delegate responsibility for formulating domestic policies to an unaccountable international organization, and seek to deflect the blame for the resulting social dislocations by using it as a scapegoat. Another implication is that international institutions seek ways of expanding their authority. Rawi Abdelal argues provocatively that the EU Commission, the OECD Secretariat and the IMF senior management played key roles in promoting the liberalization of capital controls, in part because they were competing with each other to control the issue area (Abdelal 2006, 2007). From this perspective, international institutions will generally be overprovided, and their activities should generally reduce the welfare of the relevant principals, while allowing agents to collect rents.

The theoretical debate over IMF intervention in debt rescheduling illustrates the implications of the three theoretical perspectives. In the functionalist view, the institutions of the debt regime - the IMF, the Paris Club, and the London Clubreflect the creditors' attempts to cope with moral hazard problems, which generate transaction costs. Creditors attempt to screen potential reschedulers to determine their commitment to economic reform and repayment; borrowers attempt to signal their commitment to these virtues, but also face incentives to demonstrate their need for debt relief (Cole et al. 1995). The result is often protracted negotiations while financial markets seethe with discontent. The IMF is brought into the process as a means of souring the rescheduling deal for potential defaulters (reducing the incentive to appeal for debt relief, and providing opportunities for screening and signaling), and as a means of coordinating creditor demands for economic reform. Prominent functionalist arguments are that IMF intervention facilitates debt rescheduling by overcoming the transaction costs and collective action problems that cause delay (Lipson 1985; Aggarwal 1996), or by signaling the borrowing country's willingness to implement reform (Marchesi and Thomas 1999).

To the contrary, public-choice theorists argue that the IMF seized on the Latin American debt crisis to give itself a new lease on life after the end of the era of fixed exchange rates (Vaubel 1991, Dreher 2004), and that rather than benefiting developing countries, its intervention served to strengthen the investors' position (Meltzer 2000, 47). Structural critiques emphasize that the creditor nations control the institutions, so it is unsurprising that their standard operating procedures shift most of the surplus to their own constituents. Rescheduling is a political process that rewards countries such as Mexico, Poland and Egypt that have special claims on U.S. patronage. Contrary to functionalist expectations, Bulow and Rogoff (1990) argue that IMF intervention delays rescheduling and transfers most of the surplus from any agreement to the creditors. Although IMF intervention provides incentives for debtors to compromise, it by the same token stiffens the creditors' bargaining position, and the net effect is to delay settlements. Wells (1993) analyzes a more complex incompleteinformation bargaining model, and reaches somewhat different conclusions. When the 
IMF follows its standard practice of lending only after the borrower has reached a debt servicing agreement with its creditors, Wells finds, it does shift most of the surplus to the creditors. However, when the IMF announces that it will lend to countries in arrears - as it did in the case of Mexico in 1989 under the Brady Plan - it speeds resolution of crises and transfers most of the surplus to the debtor. Recent empirical studies support this more positive assessment of the IMF's impact on rescheduling, default and interest rate spreads (Easton and Rockerbie 1999, Marchesi 2003).

Similar theoretical debates emerge throughout the recent empirical studies of IMF lending, so we find the three perspectives useful for the purposes or organizing and summarizing the findings. We hasten to add, however, that none of these perspectives is a fully developed theory that is amenable to hypothesis testing: each is underspecified, and requires a number of additional assumptions and qualifications before it can generate testable hypotheses. Furthermore, none of the three appears to be a complete account. Indeed, we conclude that recent work on the IMF provides support for generalizations that are associated with each perspective. We expect theoretical progress to come about through the construction of narrow models with well-defined microfoundations that draw on more than one of these general perspectives. An example of this kind of synthetic work is Stone (2002), which builds a formal model that draws on the functionalist ideas of institutions promoting cooperation in repeated games and the structural notion that powerful states skew the rules of the game.

While continuing to highlight the theoretical lineage, our discussion is organized in terms of the dependent variables rather than the paradigms. This approach allows us to focus attention on the breadth of new questions being addressed and assess the cumulation of knowledge on particular questions. IMF programs are typically characterized by sequential decisions: selection of countries to participate in IMF programs, design of conditions attached to programs, and implementation of conditionality; only at the end of this sequence do we observe the economic results that the program produces. We follow this sequence, and begin with work that seeks to explain which countries participate in IMF programs.

\section{Participation in IMF Programs}

The increasing methodological sophistication of IMF studies has recently generated a substantial quantity of research on participation in IMF programs. Scholars who study IMF lending want to know whether it has positive or negative effects; in order to obtain unbiased estimates of these effects, however, they are driven to explain the decision to enter IMF programs. ${ }^{5}$ Economists have pioneered the use of certain

\footnotetext{
${ }^{5}$ This is an effort to counter the effects of selection bias (Heckman 1979). Since countries typically call upon the IMF in reaction to economic crises, the sample of countries under IMF tutelage is systematically different from the overall population of states. Statistical analyses that do not correct for this self-selection are in danger of producing biased results. They potentially attribute effects to IMF lending that are really the causes of this lending. In order to avoid this pitfall, researchers increasingly use a variety of statistical models with two equations. The first equation captures program participation, and the second equation models the effect of interest. Estimation either proceeds in two steps, using an instrumental variable (IV) approach, or simultaneously for both equations, using full information maximum likelihood (FIML).

Springer
} 
political variables to explain IMF lending because they are searching for pure instruments that are unrelated to the macroeconomic variables that the Fund seeks to manipulate. On the other hand, political scientists have turned attention to the distribution of IMF programs because of an inherent interest in the politics of IMF lending, which sheds important light on the purposes of the institution. In particular, if the IMF is the tool of powerful nations, the pattern of its lending should reveal this influence.

As explanations for IMF program participation become more self-consciously political, the explanations of how politics affects IMF lending decisions are drawn increasingly from structural and public choice theory, and the functionalist paradigm appears to be less helpful. This should come as no surprise, as functionalists start from the premise of the mutually beneficial nature of cooperation (which structuralists contest), and do not focus on the individual level of decision-making (which is the perspective of public choice theory). An overview of the results of this work can be found in Tables 1,2, and 3.

The table reports signs of the coefficient estimates of variables that the authors identified as being central to their theoretical predictions, as well as a set of control variables that are widely employed. ${ }^{6}$ The variety of models used to explain participation in IMF programs and the plethora of contradictory results they produce indicates that existing models are far from definitive. This unfinished business is the strongest reason to urge caution in rushing to judgment about the effects of IMF lending. The results of analyses that correct for selection effects are only as good as the selection models used to make the corrections, so we can expect new results as the selection models are refined. Three main conclusions emerge from the current state of the literature: (1) IMF lending responds to the preferences and foreign policy objectives of the major shareholders; (2) domestic political factors play a role in determining participation in IMF programs; and (3) the results of bivariate studies indicate that borrower decisions and IMF decisions have very different motivations, which may not be captured adequately by single-equation models (e.g. Przeworski and Vreeland 2000, 2002, Vreeland 2003, Stone 2008).

One of the most robust findings that emerge from the new focus on political determinants of IMF lending is that program initiation is significantly shaped by the geopolitical preferences of the countries that contribute the most resources, particularly the United States. Several studies, following the structural approach of Thacker (1999), have measured political affinity to the United States by the similarity of a country's profile of votes in the United Nations General Assembly to those of the United States. Thacker finds that increasing this congruence over time is associated with a higher probability of IMF lending. Pop-Eleches (2007) finds the same effect, but only in post-communist countries. Barro and Lee (2005) find that IMF loans are associated with similarity to U.S. voting patterns in the UN and

\footnotetext{
${ }^{6}$ An asterisk indicates the null hypothesis for the coefficient estimate was rejected with $p=0.05$ or lower. When there are several model specifications, we report results for the one the authors identified as their 'best' model. The authors use a variety of event history approaches with discrete time intervals. The data are typically in country-year format, and a binary dependent variable captures whether a country participated in an IMF program in each year; sometimes the data are aggregated to five year intervals, and in a few cases the data are monthly.
} 


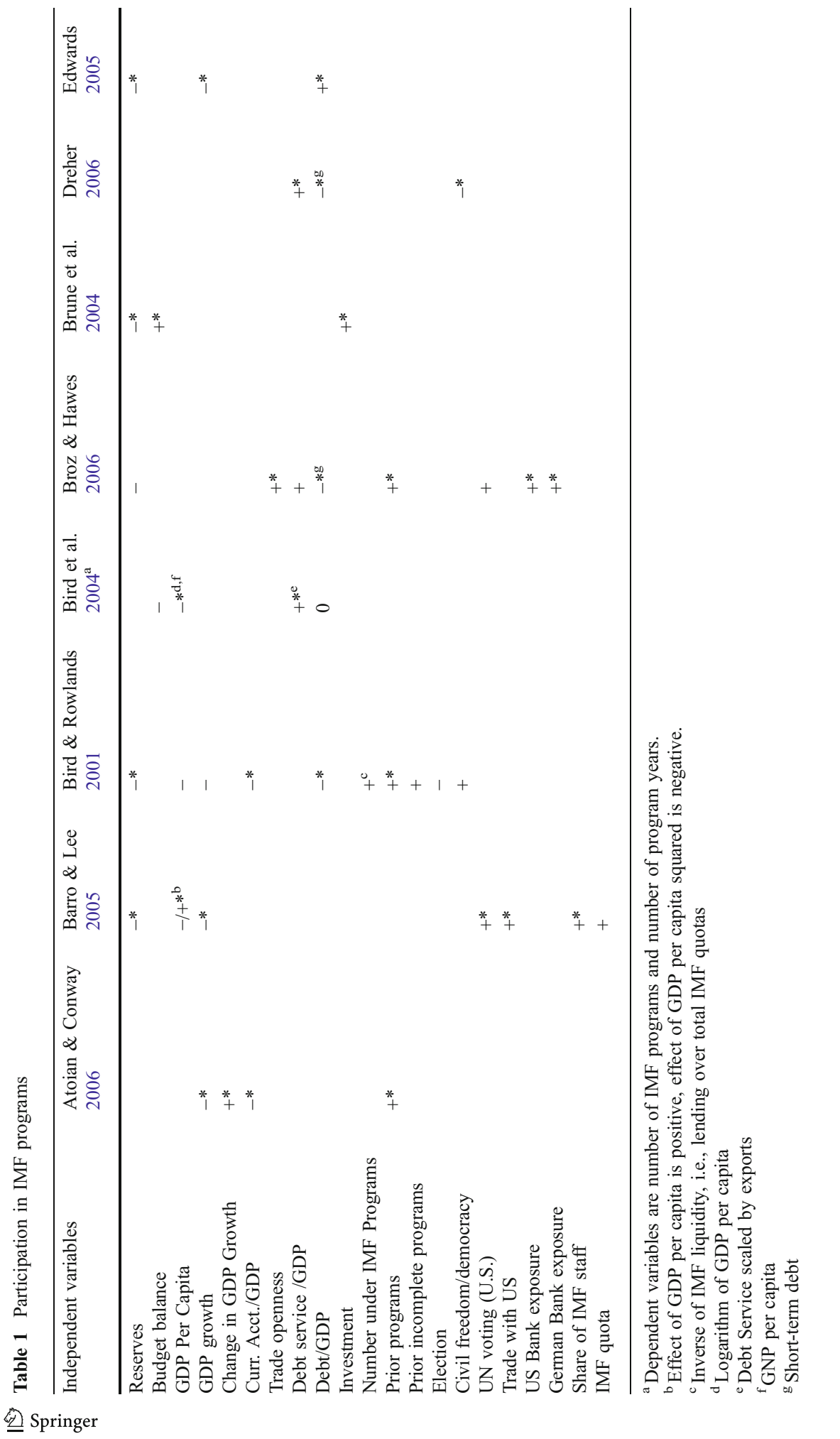


Table 2 Participation in IMF programs

\begin{tabular}{|c|c|c|c|c|c|c|c|c|}
\hline $\begin{array}{l}\text { Independent } \\
\text { variables }\end{array}$ & $\begin{array}{l}\text { Eichengreen } \\
\text { et al. } 2006\end{array}$ & $\begin{array}{l}\text { Garuda } \\
2000\end{array}$ & $\begin{array}{l}\text { Hutchison } \\
2003\end{array}$ & $\begin{array}{l}\text { Jensen } \\
2004\end{array}$ & $\begin{array}{l}\text { Nooruddin } \\
\text { \& Simmons } \\
2006\end{array}$ & $\begin{array}{l}\text { Pop- } \\
\text { Eleches } \\
2007\end{array}$ & $\begin{array}{l}\text { Sturm } \\
\text { et al. } \\
2005\end{array}$ & $\begin{array}{l}\text { Thacker } \\
1999\end{array}$ \\
\hline Reserves & + & $-*$ & -* & $-*$ & & $-*$ & $-*$ & \\
\hline Budget balance & & - & $+^{* \mathrm{~d}}$ & + & + & & & + \\
\hline GDP per capita & & & 0 & + & $-*$ & & & $-*^{\mathrm{m}}$ \\
\hline GDP Growth & -* & $-*$ & + & -* & -* & & -* & \\
\hline Curr. Acct./GDP & $+*$ & + & - & & -* & & & $-* *^{\mathrm{n}}$ \\
\hline Trade openness & $+*$ & & & & & & & \\
\hline $\begin{array}{l}\text { Change in exch. } \\
\text { rate }\end{array}$ & $+*^{\mathrm{a}}$ & & $+* \mathrm{e}$ & & & & & \\
\hline Inflation & & & & & & $-* / *^{\mathrm{f}}$ & & \\
\hline Debt service/GDP & $+* \mathrm{~b}$ & & & & & & & $+^{o}$ \\
\hline Debt/GDP & $+*$ & $+* \mathrm{c}$ & & $+*$ & & $+* \mathrm{~g}$ & & $-* \mathrm{n}$ \\
\hline Investment & & & & - & & & -* & \\
\hline Prior programs & & & & $+*$ & & $+*$ & $+* 1$ & \\
\hline $\begin{array}{l}\text { Prior incomplete } \\
\text { programs }\end{array}$ & & & & & & & & $+*$ \\
\hline Election & & & & & & & $-*$ & \\
\hline Democracy & & & & + & + & $0^{\mathrm{h}}$ & & - \\
\hline Governance & & & & & & $+*$ & & \\
\hline $\begin{array}{l}\text { UN voting } \\
\text { (U.S.) }\end{array}$ & -* & & & & & $+* i, j$ & & $+*$ i \\
\hline Trade with U.S. & & & & & & $++^{\mathrm{k}}$ & & \\
\hline US Aid & $+*$ & & & & & & & \\
\hline $\begin{array}{l}\text { US Bank } \\
\text { exposure }\end{array}$ & - & & & & & & & \\
\hline
\end{tabular}

${ }^{\mathrm{a}}$ Dummy for fixed exchange rate regime

${ }^{\mathrm{b}}$ Debt service scaled by exports

${ }^{\mathrm{c}}$ Short-term debt

${ }^{\mathrm{d}}$ Lagged change in budget surplus-real GDP ratio

${ }^{\mathrm{e}}$ Currency crisis dummy

${ }^{f}$ Positive effect for Latin America 1982-1989 and Eastern Europe 1990-2001. Negative Effect for Latin America 1990-2001.

${ }^{\mathrm{g}}$ Statistically significant only for Latin America, 1990-2001

${ }^{\text {h}}$ No or low statistical significance, varying signs of coefficient across regions and time

iSignificant only for movement towards U.S. position, not for similarity to U.S. position

${ }^{\mathrm{j}}$ Significant only in sample of ex-communist countries

${ }^{\mathrm{k}}$ US imports

${ }^{1}$ Number of past program years

${ }^{\mathrm{m}}$ GNP per capita

${ }^{n}$ Variable measured with GNP in denominator

${ }^{\circ}$ Coefficient measures interest payments per GNP

economic ties with the United States. Stone (2008) and Eichengreen et al. (2006) find that countries that receive substantial amounts of U.S. foreign aid are more likely to be eligible for IMF financing. Finally, Broz and Hawes find that high credit exposure of US and German banks increases the probability of IMF lending. The only contradictory finding comes from Eichengreen et al., who report that similarity to U.S. voting patterns in the UN decreases the chance of receiving IMF loans, after controlling for U.S. aid receipts. Although the number of studies is still small, and measures and results vary, the cumulative effect of these studies is to suggest that the 
Table 3 Participation in IMF programs

\begin{tabular}{|c|c|c|c|c|c|c|c|c|}
\hline \multirow[t]{2}{*}{ Independent variables } & \multicolumn{2}{|c|}{$\begin{array}{l}\text { Przeworski \& } \\
\text { Vreeland } 2000^{\mathrm{a}}\end{array}$} & \multicolumn{2}{|c|}{$\begin{array}{l}\text { Przeworski \& } \\
\text { Vreeland } 2002^{\mathrm{a}}\end{array}$} & \multicolumn{2}{|l|}{$\begin{array}{l}\text { Stone } \\
2008^{\mathrm{a}}\end{array}$} & \multicolumn{2}{|c|}{$\begin{array}{l}\text { Vreeland } \\
2003 b^{a}\end{array}$} \\
\hline & Govt. & IMF & Govt. & IMF & Govt. & IMF & Govt. & IMF \\
\hline Reserves & - & & - & - & $-*$ & + & $-*$ & $-*$ \\
\hline Budget balance & -* & & $-*$ & + & $+*$ & & $-*$ & + \\
\hline GDP per capita & & & & & $-*$ & & & \\
\hline Curr. Acct./GDP & & $-* \mathrm{c}$ & & $-* \mathrm{c}$ & + & + & & \\
\hline Change in exch. rate & & & & & - & $+*$ & & \\
\hline Debt Service/GDP & $+*$ & & $+*$ & + & & & $+*$ & + \\
\hline Debt/GDP & & & & & $+*$ & + & & \\
\hline Investment & $-*$ & & $-*$ & - & & & $-*$ & \\
\hline Number under IMF programs & $+*$ & $-*$ & & $-*$ & - & + & $+^{*}$ & $-*$ \\
\hline Prior programs & $++^{\mathrm{b}}$ & & $+* \mathrm{~b}$ & $-* \mathrm{~b}$ & - & & $+* \mathrm{~b}$ & $-* \mathrm{~b}$ \\
\hline Election & $+*$ & & $+*$ & - & $+*$ & & $+^{*}$ & - \\
\hline Democracy & + & & & + & $+*$ & + & $-*$ & $+* \mathrm{~b}$ \\
\hline U.S. aid & & & & & & $+*$ & & \\
\hline IMF quota & & & & & & - & & \\
\hline Missing data & & & & & & $-*$ & & \\
\hline
\end{tabular}

\footnotetext{
${ }^{\text {a }}$ Model separately estimates probability of entering agreement on part of borrowing country and IMF

${ }^{\mathrm{b}}$ Number of past program years

${ }^{\mathrm{c}}$ Balance of payments
}

preferences of the leading shareholders have a potent influence on IMF lending practices. ${ }^{7}$ This quantitative evidence therefore supports the anecdotal evidence that numerous countries that had not met the technical criteria to qualify for IMF support have nevertheless received it because they played important roles in U.S. foreign policy: Zaire and the Philippines during the Cold War; Russia, Ukraine, Egypt, Pakistan and Turkey during the 1990s. In this sense, IMF support is not dissimilar from bilateral foreign aid, which is also strongly associated with UN voting and trade patterns, and is more openly employed as a tool of foreign policy (Alesina and Dollar 2000).

A number of studies have investigated the influence of the IMF's organizational imperatives. Przeworski and Vreeland $(2000,2002)$ argue that the IMF seeks agreements that maximize its own importance. They find that the IMF is less likely to extend its help if many countries are currently participating in programs, and argue that this is because its organizational need to push loans is satiated. Barro and Lee (2005) argue that IMF lending is biased by the preferences of its staff. They find that the number of nationals serving on the IMF staff is a positive predictor of IMF lending to their countries of origin across a variety of model specifications.

Continuing in a public choice vein, Przeworski and Vreeland claim that governments sometimes turn to the IMF in order to overcome domestic opposition to policy reform. Tying policy announcements to IMF conditions increases the costs

\footnotetext{
${ }^{7}$ Sturm et al. (2005) perform an extreme bounds analysis and include a number of political variables. They fail to produce evidence for the robustness of these variables. However, extreme bounds analysis compares randomly chosen model specifications, including those that introduce omitted variable bias. Its usefulness as robustness test in research that is theoretically guided and relies on observational data is limited. 
of reneging on policy commitments, because program suspension or failure would jeopardize the borrowing country's access to private capital flows. They argue that governments choose to take the bitter medicine of IMF conditionality early in their electoral terms, because this allows them to escape punishment from a dissatisfied electorate while using IMF leverage to push through unpopular reforms (Przeworski and Vreeland 2000, 2002, Vreeland 2003b).

Bird et al. (2004) take a different approach, focusing on the incentives that lead the governments of some countries to borrow from the IMF repeatedly. They argue that IMF financing is intended for short-term balance of payments support, so longterm use of IMF financing is evidence of misuse, and may indicate that the Fund is creating a clientele of dependent states. They label repeated borrowing as "recidivism," and find that repeat users indeed constitute a distinct underclass of the international system: very poor countries with weak state institutions, weak external accounts and crushing levels of debt. An important implication of this work is that the causes of participation in IMF programs are heterogeneous, and are quite different for poor countries. A number of studies find that countries with substantial prior experience with IMF lending are more likely to borrow again, making it one of the most robust findings in the literature (Atoian and Conway 2006, Jensen 2004, Pop-Eleches 2007, Sturm et al. 2005). Studies that differentiate between government decisions and IMF choices attribute this increased tendency to the borrowers' preferences, rather than to the Fund's eagerness to extend repeat financing (Przeworski and Vreeland 2000, 2002, Vreeland 2003, Stone 2008).

Przeworski and Vreeland introduce a significant methodological refinement by distinguishing between decisions by the IMF to extend financing and decisions by particular governments to apply for assistance. ${ }^{8}$ Non-participation can result from the IMF's unwillingness to lend or from the government's reluctance to ask for assistance. These are distinct reasons for non-participation, and are thus unlikely to be captured well by a single equation. We do not typically observe whether the countries that did not participate applied for support and were rejected, or would have been extended financing but refrained from applying for it. Using a bivariate probit model, it is possible to obtain estimates of both decisions if one is able to make identifying assumptions that rely upon strong priors; the validity of the inferences drawn, however, depends upon the solidity of these priors. ${ }^{9}$

The IMF participation studies demonstrate some areas of consistency, but also a number of areas of disagreement. Several studies have found macroeconomic variables

\footnotetext{
${ }^{8}$ In addition, Przeworski and Vreeland estimate models that differentiate between the signing of an IMF agreement and the continuation of existing IMF programs. This also improves the specification of the model, because the factors conducive to program initiation and the processes governing the length of a program are likely to be theoretically distinct. For the bivariate probit models in this vein (Przeworski and Vreeland 2000, 2002, Vreeland 2003, Stone 2008), Table 3 reports two columns of results, one for IMF decisions and one for country decisions, but only the results for program initiation.

${ }^{9}$ There are other concerns with the Poirier bivariate probit model with partial observability (Poirier 1980). The model is guaranteed only to be locally identified when rank and order conditions are satisfied; additional identifying restrictions may be necessary in order to assure that it is globally identified. In addition, these models are highly unstable unless they are over-identified. The theoretical validity of inferences, the concern for global identification and the issue of robustness all point to the need for finding additional variables that explain only government choices or only IMF choices, and this will be the priority for future research on participation in IMF programs.
} 
to have effects consistent with the intuition that countries turn to the IMF for support when they have weak external accounts. Low levels of international currency reserves and large current account deficits increase the probability of requiring IMF assistance. From a functionalist perspective, this suggests that the IMF continues to function as a lender of last resort, although the international financial system has dramatically changed since the demise of the Bretton Woods system of fixed exchange rates.

The findings become less firm when we disaggregate decisions by the Fund and decisions by borrowing countries. While borrowers clearly are more interested in participating in IMF programs when their current account and reserve positions become weak, the results are less clear for the IMF. Przeworski and Vreeland find that the association between currency reserves and the IMF decision to offer a program is insignificant (Przeworski and Vreeland 2002, Vreeland 2003), although they do find that the IMF is significantly more likely to extend financing to countries with current account deficits (Przeworski and Vreeland 2000, 2002). Using the same method, but more recent time periods and additional identifying assumptions, Stone (2008) finds that the IMF is actually less likely to extend financing when foreign reserves and the current account are particularly grim. He argues that this may have changed after the Fund's recent experiences of unsuccessful bailouts, and could indicate that the IMF is risk averse and seeks to protect its reputation by avoiding programs that are likely to fail. This suggests that the Fund's functional role as lender of last resort is subject to some of the constraints theorized by public-choice perspectives.

Debt service displays an unambiguous effect across a wide selection of models. Without exception, high burdens of debt service increase the likelihood of IMF program participation. This finding is consistent with the IMF's role as lender of last resort for indebted governments; again, however, analyses that disaggregate participation into IMF and country decisions find that the effect is due to the increased eagerness of national authorities to seek assistance rather than to an accommodating posture on the part of the Fund (Stone 2008). Equally intuitive is the negative effect of GDP growth on the probability of IMF lending. Ten studies include this variable, and it attains statistical significance in eight cases. Five of eight studies that test the effects of GDP per capita find a statistically significant relationship: richer countries are less likely to receive IMF funding. One study tests a nonlinear specification and finds that the coefficient on the squared term takes on a negative sign, while the linear term is positive, and the authors argue that the IMF is reluctant to provide financing to the poorest and least creditworthy countries, while very rich countries do not apply (Barro and Lee 2005). Testing this interpretation calls for a bivariate approach, which the authors do not use. Consistent with the other studies, they report that the overall marginal effect of GDP per capita at the sample mean is negative. Low investment flows also seem robustly related to an increased probability of IMF lending. Seven of nine studies find this relationship, at varying levels of statistical significance, with one significant finding pointing in the opposite direction (Brune et al. 2004). A mixed picture emerges regarding the effects of the budget balance, and debt levels as a share of GDP: there are some positive and some negative statistically significant findings, and a number of statistically insignificant coefficients.

In summary, students of the factors that influence IMF lending and program participation have identified a number of important causal relationships. There is evidence for the influence of powerful shareholders and for the relevance of 
domestic politics and organizational self-interest in IMF lending decisions. Statistical models that focus on the structure of the decision making process suggest that the IMF and borrowing countries entertain very different objectives. Finally, macroeconomic aggregates associated with the IMF's task as guarantor of global economic stability continue to serve as reliable predictors of IMF lending. On the theoretical side, structural and public choice approaches have clearly ended the monopoly of functionalism in studies of the IMF. This is in part a result of methodological developments. The need to deal with the issue of sample selection drives empirical researchers to pay more attention to the micro-foundations of IMF lending decisions. Over time, therefore, we are witnessing a desirable convergence between methods and theory, as the demands of statistical methods drive researchers to construct more sophisticated political explanations for IMF lending.

\section{Conditionality Under IMF Programs}

When the IMF extends a program, it makes its financial support conditional upon a set of policy conditions that the participating country agrees to uphold. Formally, the borrowing country enters into a voluntary and legally non-binding agreement, summarized in a "letter of intent." Conditionality typically includes macroeconomic policy adjustments and structural reforms, such as trade liberalization and the privatization of state assets. The IMF has often been criticized for applying one-sizefits-all economic policy prescriptions without sensitivity to context and ignoring borrowers' domestic political constraints (e.g., Meltzer 2000, Easterly 2001, and Stiglitz 2002). The prescribed economic reforms have been criticized for redistributing wealth away from the poorest groups in society, at least in the short run. Conditionality therefore has been targeted either as inherently unjust, or as only furthering the economic interests of the rich Western countries that dominate the IMF.

The recent wave of quantitative studies of conditionality became feasible only in recent years, with the publication of letters of intent on the IMF web page and the opening of the IMF archives. ${ }^{10}$ The emerging evidence indicates that even in core areas of conditionality such as fiscal adjustment, IMF programs vary widely in the degree of fiscal adjustment required, whether revenue or expenditure reforms are chosen to implement the adjustment, and the scope of structural reform involved (IEO 2003a, b). Researchers who make use of these new data draw hypotheses from all three paradigms: functionalist, structural and public choice. From a functionalist perspective, conditionality is a critical tool that induces the prudent economic behavior necessary to arrive at the desirable (functional) effects of IMF programs. Structural views expect the pattern of conditionality to reflect the interests of major shareholders, and particularly of the United States. From a public choice perspective, conditionality serves the institutional self-interest of IMF staff. ${ }^{11}$ Table 4 provides an overview of the dependent variables the authors employ and the effects they find.

\footnotetext{
${ }^{10}$ Vreeland (2006) discusses the previous generation of studies of IMF conditionality.

${ }^{11}$ Alternatively, it may represent their preferences and training. Chwieroth (2007) tests for an effect of neoclassical training of IMF staff (which increases over time) on the likelihood of capital account liberalization in program countries, but without observing whether those measures are included in conditionality.
} 
Table 4 Conditionality

\begin{tabular}{|c|c|c|c|c|c|c|c|c|}
\hline & $\begin{array}{l}\text { Gould } \\
2003\end{array}$ & $\begin{array}{l}\text { Ivanove } \\
\text { et al. } \\
2003\end{array}$ & $\begin{array}{l}\text { a Dreher } \\
2004\end{array}$ & $\begin{array}{l}\text { Drehe } \\
\text { and } \\
\text { Vaube } \\
2004 b\end{array}$ & $\begin{array}{l}\text { r Copelovitch } \\
2005\end{array}$ & $\begin{array}{l}\text { Gould } \\
2006\end{array}$ & $\begin{array}{l}\text { Dreher } \\
\text { and } \\
\text { Jensen } \\
2007\end{array}$ & $\begin{array}{l}\text { Stone } \\
2008\end{array}$ \\
\hline & \multicolumn{8}{|c|}{ Dependent Variable } \\
\hline $\begin{array}{l}\text { Independent } \\
\text { variables }\end{array}$ & $\begin{array}{l}\text { Inclusion } \\
\text { of bank- } \\
\text { friendly } \\
\text { conditions }\end{array}$ & & Number & r of IM & F conditions $\mathrm{e}^{\mathrm{e}}$ & & & $\begin{array}{l}\text { Scope of } \\
\text { imposed } \\
\text { conditions }\end{array}$ \\
\hline Opennesss & & & $-{ }^{* \mathrm{~b}}$ & & & & & - \\
\hline Current account & & & $-^{*}$ & $+{ }^{* g}$ & & & & \\
\hline Government budget deficit & & & & $-{ }^{* \mathrm{~g}}$ & & & - & \\
\hline Monetary expansion & & & & + & & & $+^{*}$ & \\
\hline Reserves & + & & & $-\mathrm{g}$ & $-^{*}$ & + & - & \\
\hline GDP per capita & $-^{\mathrm{a}}$ & - & $-{ }^{\mathrm{d}}$ & $-{ }^{*} \mathrm{~d}$ & & $-^{\mathrm{a}, \mathrm{d}}$ & $-{ }^{*} \mathrm{~d}$ & 0 \\
\hline World Bank adjustment loans & & & $+^{*}$ & + & & & & \\
\hline Short term debt & & & & & $-^{*}$ & & & \\
\hline LIBOR & & & & $+^{*}$ & & & $+^{*}$ & \\
\hline Bilateral debt & & & & & & $-*$ & & \\
\hline GDP growth in OECD countrie & & & & & & & $+^{*}$ & \\
\hline Countries under IMF programs & & & & & & & & $+^{*}$ \\
\hline IMF quota review & & & & & $-^{*}$ & & & \\
\hline Program duration & & + & & & & & & $-^{*}$ \\
\hline Low capacity & & & & & & & & $-^{*}$ \\
\hline Selective reporting & & & & & & & & + \\
\hline Private influence & $+^{*}$ & & & & & & & \\
\hline US influence & - & & $+^{\mathrm{c}}$ & & - & & & $+{ }^{* \mathrm{f}}$ \\
\hline Regime & + & & + & & & + & & $-{ }^{*}$ \\
\hline Left-right & & & & & & & & + \\
\hline Presidential & & & & & & & & $-{ }^{*}$ \\
\hline Selection correction & No & No & No & No & No & No & No & Yes \\
\hline
\end{tabular}

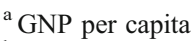

${ }^{\mathrm{b}}$ Index measuring economic freedom

${ }^{\mathrm{c}}$ US military grants and US loans, relative to IMF disbursements

${ }^{\mathrm{d}}$ Not standardized per capita

${ }^{\mathrm{e}}$ Ivanova et al. use IMF conditions per program year. Gould distinguishes target oriented from procedural conditions, but finds similar results

${ }^{\mathrm{f}}$ Similarity to US voting in UN full assembly. US foreign aid is not statistically significant

${ }^{\mathrm{g}}$ Variable is instrumented

Dreher (2004), Dreher and Vaubel (2004b), and Ivanova et al. (2003) investigate the number of conditions the IMF imposes, while Stone (2008) analyzes the breadth of conditionality. Gould (2006) distinguishes between target conditions and procedural conditions. The former spell out performance goals for certain macroeconomic measures, while the latter not only set goals, but also specify the policies to be implemented in order to reach them. Each study finds substantial variation in the pattern of conditionality across countries and an upward trend in conditionality over time. With the exception of Gould (2006), studies that differentiate according to the type of programs find that participation in programs designed for low-income countries (PRGF or ESAF) involve less extensive 
conditions. Ivanova et al. and Dreher find no evidence that political variables affect the pattern of conditionality, although Dreher finds that lower levels of economic freedom in the recipient country are associated with more conditions. Stone finds evidence that both domestic political conditions in the borrowing country and international strategic factors influence the pattern of conditionality. Only Stone corrects for selection effects.

Dreher (2004) takes a public choice perspective, arguing that the IMF prefers to impose as many conditions as possible in order to increase the prestige, budget and organizational slack of the organization, and explains variations in the number of conditions in terms of shifts in the relative bargaining power of the Fund and its borrowers. As evidence, he cites associations between the number of conditions and weak current accounts and heavy dependence on financing from the IMF and World Bank. In contrast, Stone (2008) finds that while countries apparently desire to minimize conditionality, the Fund often refrains from imposing maximum conditionality when it is in a strong bargaining position. In addition, countries that receive substantial amounts of U.S. foreign aid are subject to more stringent applications of conditionality when their need for IMF support is greatest.

In contrast to the focus on powerful state actors and institutional self-interest discussed so far, Gould (2003) and Copelovitch (2005) are interested in how the interests of private investors shape the content of conditionality. Gould (2006) investigates supplementary financing by creditor states, private financial institutions, and multilateral institutions, and argues that private investors influence conditionality because the IMF needs to attract private financing to supplement its own lending. In a blend of functionalist and public choice perspectives, she finds that IMF decision makers accommodate the wishes of the financial community in order to ensure that the IMF is able to fulfill its role as guarantor of financial stability. Copelovitch (2005) blends structural and public choice perspectives, arguing that investors influence the content of conditionality only when they can call upon the interests of G-5 countries, but that this influence disappears when coordinated banks are replaced on the international scene in the 1990 s by uncoordinated portfolio investors.

To sum up, studies of conditionality have only begun to appear, but the new data that the IMF has begun to reveal make it apparent that the notion of the IMF program as a homogeneous unit is false. IMF programs vary as much as the IMF's borrowers. Some are detailed prescriptions for systemic change, and others are limited pledges to constrain the growth of the national debt. An extreme example is the program introduced in Ukraine on the eve of its financial collapse in 1998, which contained 227 prior actions and performance criteria (Ukraine 1998). Studies of program effects typically assume that these effects are uniform; but if conditionality matters, program effects should vary with the substantive conditions that are required. $^{12}$ On the theoretical side, international investors, powerful shareholder countries, and the IMF's own organizational imperatives vie with each other to set the pattern of conditionality, and there is empirical support for each kind of influence. Future research should aim to integrate state power and organizational

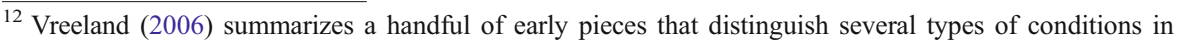
studying program compliance.
} 
interests into coherent models, so that we can learn more about the mechanisms in play by testing these particular models against each other.

\section{Program Implementation}

Program implementation and enforcement have long been neglected by researchers, but this is changing rapidly, and our survey features eleven studies (for an overview see Tables 5 and 6). From a functionalist perspective, the success of IMF programs in restoring investor confidence and aiding economic recovery is conditional on whether the economic reforms that the IMF prescribes are implemented. Taking a structural point of view, powerful shareholders may attempt to shield favored client states from the consequences of their failure to comply with conditionality.

Ivanova et al. (2003) find that implementation is highly problematic: seventy percent of programs are suspended at some point for non-compliance. ${ }^{13}$ Program interruptions increase with the severity of domestic political constraints: ethnic divisions, the presence of parochial groups in parliament, the number of parties forming a coalition government, and divided government. Stone (2002) and Arpac et al. (2006) similarly find that program interruptions are associated with multi-party coalition governments. Along similar lines, Simmons (2000a, b) finds that countries with weakly established rule of law were most likely to renege on Article VIII commitments. Democracy appears to be associated with successful implementation, and authoritarian or weakly democratic regimes are more likely to experience program interruptions (Stone 2002, 2004 and Nsouli et al. 2006), although PopEleches (2007) finds evidence for a reversed effect. In a similar contradiction, Dreher (2003) finds that democratic states have a lower credit disbursementcommitment ratio, while Joyce (2006) finds the opposite.

Stone (2002) argues that the IMF's lending decisions in important cases are politicized, so it is unable to credibly threaten to withhold financing from countries that have significant international influence. Four studies are concerned with the question of U.S. influence, and all find supporting evidence for the argument. Stone (2002) finds that post-Communist countries that receive large amounts of U.S. foreign aid are punished by the IMF for shorter periods on average, albeit more often. Favored countries cannot credibly be subjected to the rigorous treatment that the IMF offered less prominent borrowers, and are consequently less inclined to implement politically risky reforms. Stone (2004) finds a similar pattern in Africa, although with local variations. As in Eastern Europe, African countries that receive substantial U.S. foreign aid, such as Egypt, are subject to less rigorous enforcement. However, the United States is not the only country that interferes with enforcement in Africa: membership in British- and French-sponsored post-colonial international institutions, and voting with France in the United Nations General Assembly, also predict weak program enforcement. Countries with less rigorous enforcement violate their conditions more often, and have more frequent program suspensions. Using a

\footnotetext{
${ }^{13}$ As measures of IMF program implementation, the authors use temporary and permanent program interruptions, the fraction of implemented macroeconomic and structural conditions, and the ratio of disbursements to the overall size of the loan package.
} 


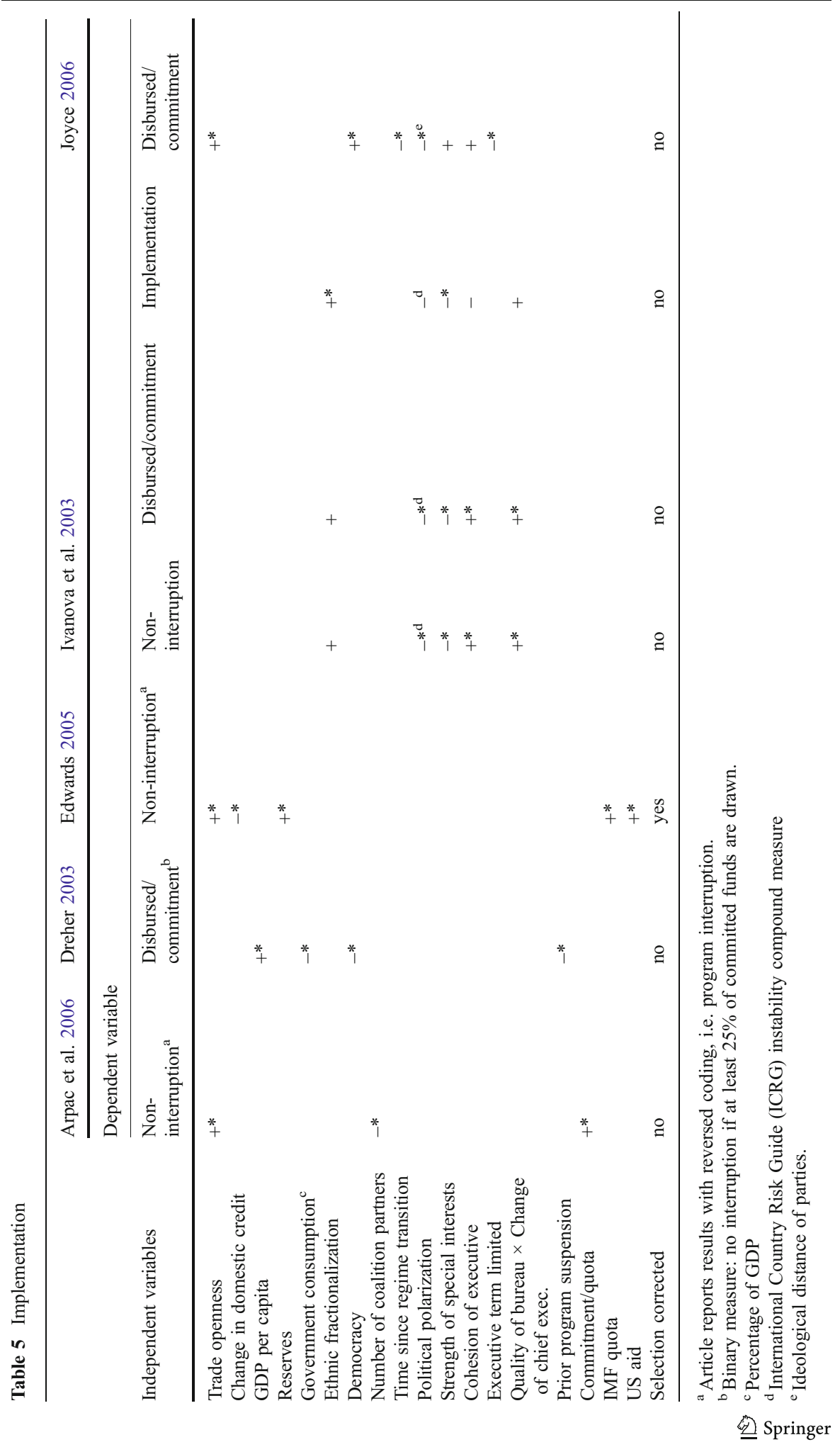




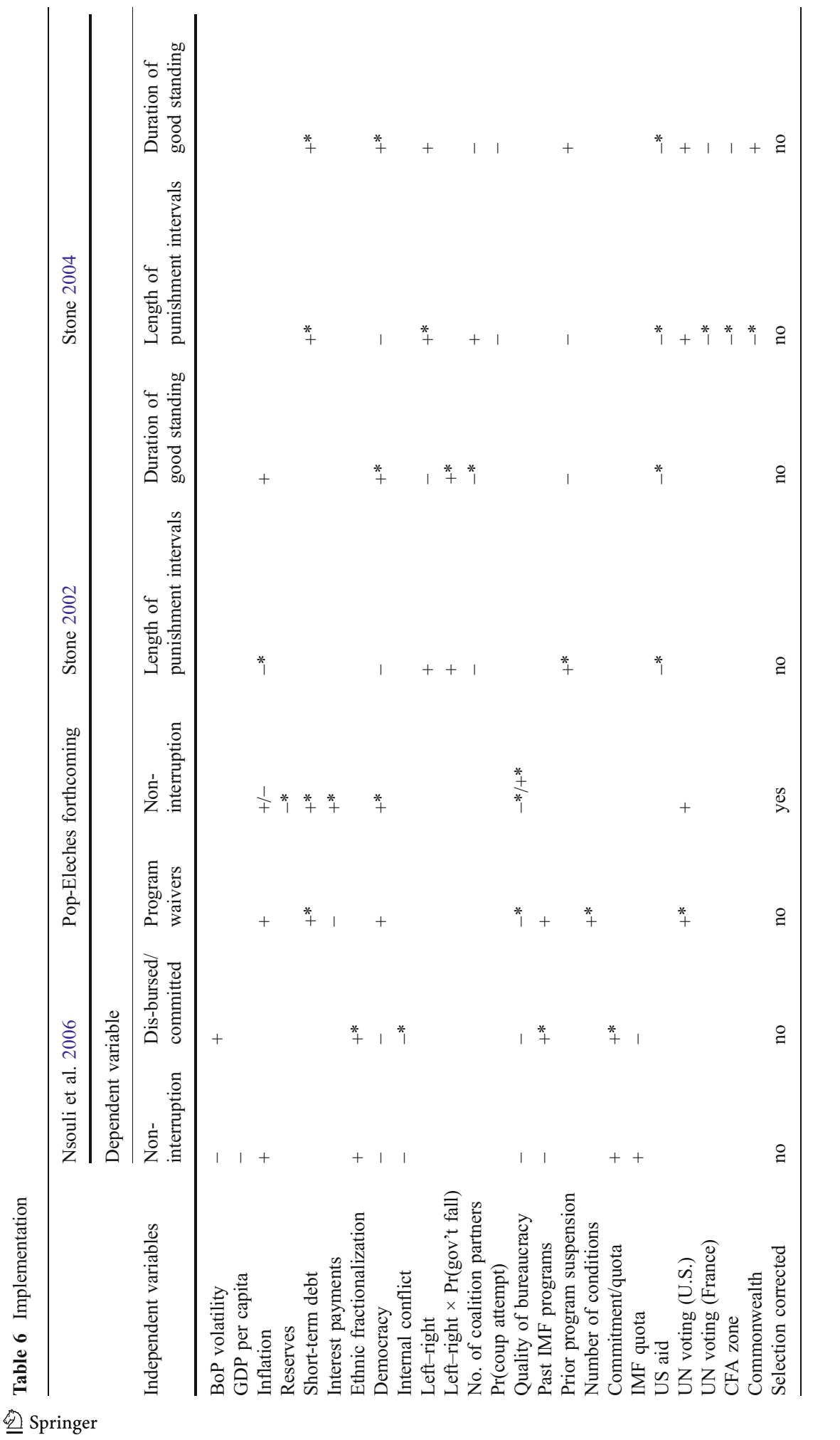


sample that encompasses several regions, Edwards (2005) also finds that US aid decreases the probability of programs interruptions. In addition, Pop-Eleches (2007) finds that states with voting patterns similar to the United States in the UN general assembly have a lower probability of program interruptions.

Studies of the implementation and enforcement of conditionality have only recently begun to appear, but already general patterns are discernible. On the domestic level, governments seem to be constrained in their ability to implement IMF conditionality by political fragmentation and instability. On the international side, the IMF is subject to cross-pressures from its biggest shareholders that lead to inconsistent enforcement of conditionality and interfere with its mission as a guarantor of market stability. Taken together, these variations related to implementation and enforcement constitute a second broad category of unobserved heterogeneity that confounds efforts to assess the effectiveness of IMF programs. Effects of programs should differ depending upon implementation, and variations in the credibility of enforcement should affect both the implementation of the agreedupon reforms and market expectations.

\section{Catalytic Effects and Program Outcomes}

Evaluating the effects of programs was the first task to receive quantitative treatment in studies of the IMF and has generated the most extensive literature, yet it is the question about which our judgments must remain most tentative. There are two reasons for this. First, selection effects are most pronounced in assessments of program effects, and they have not yet been adequately addressed. A reliable assessment of the effects of IMF lending will have to wait for convincing solutions to selection problems. Second, these studies are plagued by issues of unobserved heterogeneity of borrowers and treatments. The pattern of conditionality varies across programs, and different conditions should have different effects; implementation varies across borrowers, and policy reforms only affect outcomes if they are implemented; enforcement varies across borrowers, affecting both the implementation of IMF conditions and market expectations about the likelihood of reform.

Notwithstanding these difficulties, methodological developments in the last five years have helped to uncover important new findings about the effects of IMF lending. In particular, we find evidence that controlling for selection effects matters. The question about program effects that has received the most attention in recent years is how IMF lending affects economic growth. Here a clear divide emerges (see Table 7). Of the four works that do not control for selection effects, two fail to produce a statistically significant finding, and two identify a positive relationship between growth and program participation. In contrast, seven out of eight works that do control for selection consistently identify a statistically significant negative relationship.

Judging by recent evidence, IMF programs are a mixed blessing. On the negative side, program participation appears to reduce economic growth and leads to more inequality, as captured by a decreasing income share of labor, and lower public spending on health and education. On the positive side, IMF intervention seems 


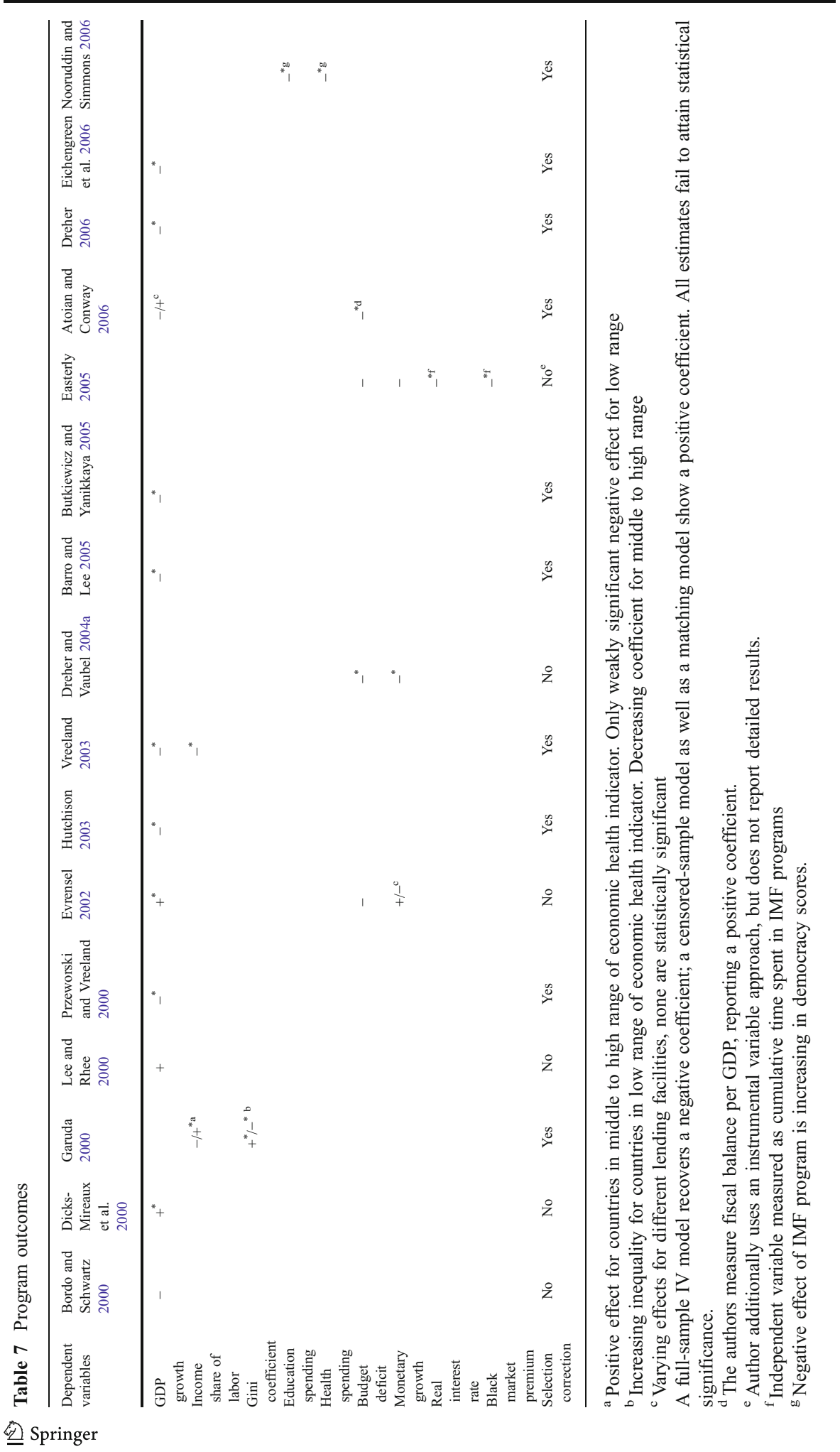


effective in stabilizing budget deficits and other important macroeconomic indicators. Credible IMF programs can lower inflation levels and monetary growth.

A recent exchange in the American Political Science Review highlighted the importance of selection effects. Simmons (2000a, b) studies the effects of Article VIII commitments, which are pledges to refrain from imposing restrictions on current account transactions, and the conditions under which states violate those commitments. Accession to Article VIII is voluntary. Simmons argues that making a commitment not to violate Article VIII norms makes countries less likely to do so, and finds that adopting the commitment decreases a state's probability of imposing current account restrictions, even when controlling for economic factors and political variables. Her findings were challenged by von Stein (2005), who argued that most of the effect that Simmons attributed to adopting an Article VIII commitment is really attributable to unobservable factors that make states willing to adopt such a commitment. She reproduced Simmons' (2000b) analysis, using a Heckman-type selection model, and found the effect of Article VIII to be much more modest than Simmons had found and to be limited to the year immediately following the commitment. In response, Simmons and Hopkins (2005) argue that von Stein's findings can be attributed in large part to model specification choices, rather than to selection effects, and go on to show that Simmons' original finding is supported by an alternative model that imposes less demanding assumptions on the data. The three articles indicate how critical it can be to address selection issues, but also that simply addressing selection does not resolve the matter, because the adequacy of selection corrections depends upon substantive identification issues and modeling choices. ${ }^{14}$ Substantive conclusions about the effects of the IMF's activities continue to depend upon the methods that we use to explain when countries engage with the IMF.

An important recent wave of research focuses on the policy-relevant claim that IMF programs act as catalyst for stimulating private capital flows. IMF resources are small relative to the financial needs of many debtor governments and to aggregate official and private capital flows. The success of IMF intervention during financial crises therefore crucially rests on how much additional private capital flows into a country because of an IMF program, or its catalytic effects. Catalytic effects are distinct from traditional measures of program outcomes in that they build on explicit theoretical insights about how the IMF changes the incentives of key economic actors. If catalytic effects are substantial, they serve to legitimize conditionality and create incentives for program implementation (IMF 2002).

One clear finding of this new literature is that the catalytic effects of IMF lending are not uniform across countries. Indeed, theoretical models that emphasize the IMF's credibility problems would lead us to expect substantially different effects across countries, and models that emphasize the variety of reasons that lead countries to participate in programs would lead us to expect private investors to draw different inferences from apparently similar signals. This might lead us to expect that studies that search for monotonic catalytic effects would fail to find them, and the results of such studies are indeed mixed and inconclusive (see Table 8). On the positive side, IMF program participation seems to increase the

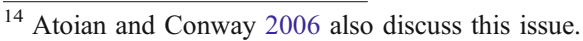


Table 8 Catalytic effects of program participation

\begin{tabular}{|c|c|c|c|c|c|c|}
\hline $\begin{array}{l}\text { Independent } \\
\text { variables }\end{array}$ & $\begin{array}{l}\text { Bird and } \\
\text { Rowlands } 2002\end{array}$ & $\begin{array}{l}\text { Brune et al. } \\
2004\end{array}$ & $\begin{array}{l}\text { Edwards } \\
2005\end{array}$ & $\begin{array}{l}\text { Eichengreer } \\
\text { et al. } 2007\end{array}$ & $\begin{array}{l}\text { Jensen } \\
2004\end{array}$ & $\begin{array}{l}\text { Mody and } \\
\text { Saravia } 2003\end{array}$ \\
\hline $\begin{array}{l}\text { Sudden stop of } \\
\text { capital flow }\end{array}$ & & & & $-^{*}$ & & \\
\hline Private debt &,$+-^{* a}$ & & & & & \\
\hline $\begin{array}{l}\text { Portfolio debt } \\
\text { flows }\end{array}$ &,$+{ }^{*}{ }^{* a}$ & & $++^{* \mathrm{c}}$ & & & \\
\hline $\begin{array}{l}\text { Privatizations } \\
\text { (volume) }\end{array}$ & & $+^{*}$ & & & & \\
\hline Bond spreads & & & & & &,$+-{ }^{* b}$ \\
\hline FDI flows & $-{ }^{* a}$ & & & & $-^{*}$ & \\
\hline $\begin{array}{l}\text { Selection } \\
\text { correction }\end{array}$ & No & Yes & $\mathrm{Yes}^{\mathrm{d}}$ & Yes & Yes & Yes \\
\hline
\end{tabular}

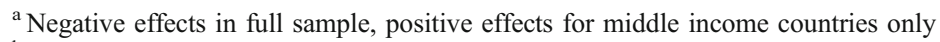

${ }^{\mathrm{b}}$ Bond spreads are lower under an IMF program for middle range values of foreign exchange reserves. For very high and very low reserve values, bond spreads are higher.

${ }^{\mathrm{c}}$ Conditional on successful program implementation

${ }^{\mathrm{d}}$ Corrects for program selection and implementation
}

market value of state enterprises that come up for privatization (Brune et al. 2004), increase private capital flows (Edwards 2005), and make sudden stops of capital flows less likely (Eichengreen et al. 2006). On the negative side, two studies find IMF lending to be associated with a decrease in foreign direct investment (Bird and Rowlands 2002, Jensen 2004). ${ }^{15}$

Studies that investigate the possibility of non-monotonic effects, on the other hand, find positive catalytic effects only for countries in a middle range of economic indicators for wealth or financial stability (Mody and Saravia 2003, Bird and Rowlands 2002). At the extremes, those effects fade or even reverse. Mody and Saravia analyze launch spreads of private and government bonds over risk-free rates. Their findings show that IMF program participation lowers the spread for countries with medium levels of foreign reserves. Countries at the high end of foreign exchange reserve holdings are subject to larger bond spreads under an IMF program, while countries with very low reserves experience neither a positive nor a negative catalytic effect. Bird and Rowlands find that IMF lending increases capital inflows for middle-income countries, but the effect washes out or even turns negative in the sample of all countries. ${ }^{16}$ The non-monotonic or "u-shaped" pattern that emerges from this new line of research provides further evidence that theoretical explanations and statistical models of IMF program outcomes need to account for heterogeneity among borrowing countries. Mody and Saravia suggest that non-monotonicity results from the signaling function IMF programs perform for private economic

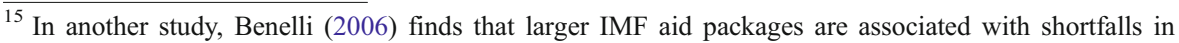
actual versus predicted private capital flows. We do not count this as evidence for negative catalytic effects, since those require comparing counterfactual cases of countries without IMF program to those with program.

${ }^{16}$ Exceptions are private debt flows which react negatively to IMF lending under the Extended Fund Facility for middle income countries, and positively in the full sample.
} 
actors. Future theoretical work, formal and otherwise, should seek to account for this empirical pattern.

Policymakers will be disappointed to learn that the most sophisticated techniques have yet to forge a consensus on the effects of IMF lending, but researchers will be encouraged to see that there is a rich agenda for future work. Although this was the first area of IMF activity to receive systematic empirical attention, it has been revitalized by both theoretical and methodological innovation. One consequence is that much of what we thought we knew about the effects of IMF lending has to be reevaluated. The focus on economic actors and catalytic effects demonstrates the essential role that theory can play in reshaping an empirically driven research agenda. The new focus on selection effects illustrates how better empirical models demand a theoretically informed understanding of the political and economic processes that give rise to the data. Further convergence of theory and methods should improve the reliability of empirical findings and put our conclusions about IMF program outcomes on a firmer basis.

\section{Conclusions}

The recent work on IMF program effects clearly demonstrates that selection effects are important. Studies that fail to correct for selection effects produce biased estimates, and the biases can be large if the populations of participating and nonparticipating countries are substantially different in ways that affect our dependent variables. The new studies that analyze IMF participation provide new insights as to why the biases may be substantively important, and the studies that correct for selection demonstrate that this is, indeed, the case. In spite of this important progress, the expanding research agenda reviewed above indicates how far we remain from a satisfactory model of IMF effects. Four main directions remain for improvement: (1) refinement of existing selection models; (2) modeling borrower heterogeneity; (3) modeling variations in conditionality; (4) modeling variations in enforcement.

The multiplication of studies that explain participation in IMF programs in recent years makes a survey like this possible, but their numerous contradictory results indicate a clear agenda for future research. Models of program participation will have to take account of functionalist, structural and public choice perspectives. Gone are the days of selection models based on only economic variables. Furthermore, the next generation of selection models should include bivariate studies, reflecting the mounting evidence that borrower decisions and IMF decisions have different motivations that are distorted by single-equation models. These bivariate studies, in turn, will demand theoretical attention to their critical identifying restrictions. We should expect the refinement of selection models to yield new substantive findings about the effects of IMF programs.

Borrower heterogeneity has important implications that are not exhausted by correcting for selection bias. This survey indicates three kinds of heterogeneity that have only begun to be explored in the literature on program effects: (1) capital market effects, (2) recidivism, and (3) implementation. First, the literature on catalytic effects strongly suggests that the effects of IMF lending on capital markets are not uniform across borrowers, but rather depend upon borrower characteristics 
such as the level of development, the depth of capital markets, and the level of foreign reserves. In short, the catalytic effects that form a logical prerequisite for the effectiveness of IMF intervention may only exist under certain circumstances, and studies of IMF effectiveness should take these conditional effects into account. Second, prolonged users of IMF programs may behave differently than other countries that draw upon IMF support only intermittently to deal with liquidity crises. If these repeat users are poor countries with weak states, it is unlikely that they will implement IMF programs effectively or attract substantial capital flows as a result. Third, if the implementation of programs varies substantially because domestic political constraints and weak institutional capacity prevent countries from carrying out reform, or alternatively because interference by the states that are the leading IMF shareholders creates credibility problems, this should lead to variation in implementation and consequent variation in program effects.

Conditionality is an area that has only begun to be explored, using data that the IMF has begun to reveal in recent years, but one key conclusion comes through clearly: IMF programs are not homogeneous. IMF programs vary substantially in their breadth and in the types of problems they are designed to address. A new research agenda has opened up that will attempt to explain the pattern of conditionality. For traditional studies of the effects of IMF programs, however, the implication is clear: there is no coherent reason to expect heterogeneous treatments to have homogeneous effects. Consequently, the question should shift from the effects of IMF programs to the effects of particular kinds of IMF programs, with particular performance criteria.

Enforcement is a new item on the research agenda, but already it is clear that enforcement varies substantially across countries. The IMF is able to credibly commit to enforcing programs in small, poor countries, but finds it difficult to enforce programs when the borrowers are important clients of the United States or other major shareholder countries. A contract is only worth what can be enforced. If the IMF's conditionality contracts are unenforceable, it should be no surprise that they have no positive effects. Studies of effects, therefore, would do well to control for variations in enforcement.

Much remains to be learned from quantitative studies of the IMF. In fact, quite apart from the normative questions about how its performance ought to be evaluated, we have to be very cautious in our claims about the effects of IMF lending. On the other hand, a burst of quantitative research on the IMF in the last 5 years has taught us important things about which countries participate in IMF programs, what determines the conditions attached to them, and what determines the degree to which these conditions are enforced and implemented. In particular, we now have a strong empirical basis for the claim that IMF lending is skewed by the foreign policy priorities of the United States at all stages of the project cycle, from borrower selection through program design and on to enforcement. We also have evidence that these enforcement difficulties lead to failure to implement IMF conditions. Therefore, while our judgments should be tempered by uncertainty about the effects of IMF lending, there is nevertheless strong reason to believe that interference by the IMF's principals undermines the IMF's efforts to achieve its objectives. This timeinconsistent behavior may, in fact, be suboptimal for borrowers and shareholders alike. 


\section{References}

Abdelal, R. (2006). Writing the rules of global Finance: France, Europe, and capital liberalization. Review of International Political Economy, 13, 127.

Abdelal, R. (2007). Capital Rules: The Construction of Global Finance. Cambridge, Mass.: Harvard University Press.

Aggarwal, V. K. (1996). Debt games: Strategic interaction in international debt rescheduling. Cambridge: Cambridge University Press.

Alesina, A., \& Dollar, D. (2000). Who Gives Aid to Whom and Why? Journal of Economic Growth, 5, 3363 (March).

Arpac, O., Bird, G., \& Mandilaras, A. (2006). What determines the implementation of IMF programs? University of Surrey Discussion Papers in Economics DP 18/06.

Atoian, R., \& Conway, P. (2006). Evaluating the impact of IMF programs: A comparison of matching and instrumental-variable estimators. Review of International Organizations, 1, 99-124.

Barro, R. J., \& Lee, J-W. (2005). IMF programs: who is chosen and what are the effects? Journal of Monetary Economics, 52, 1245-1269.

Benelli, R. (2006). Do IMF-supported programs boost private capital inflows? The role of program size and policy adjustment. In A. Mody, \& Rebucci A. (Eds.), IMF Supported Programs: Recent Staff Research (pp. 35-51). Washington, D.C.: International Monetary Fund.

Bird, G., Hussain, M., \& Joyce, J. P. (2004). Many happy returns? Recidivism and the IMF. Journal of International Money and Finance, 23, 231-251.

Bird, G., \& Rowlands, D. (2001). IMF lending: how is it affected by economic, political and institutional factors? Journal of Policy Reform, 4, 243-270.

Bird, G., \& Rowlands, D. (2002). Do IMF programmes have a catalytic effect on other international capital flows? Oxford Development Studies, 30, 229-249.

Bird, G. (2007). The IMF: A bird's eye view of its role and operations. Journal of Economic Surveys, 21, $683-745$.

Bordo, M., \& Schwartz, A. J. (2000). Measuring real economic effects of bailouts: historical perspectives on how countries in financial distress have fared with and without bailouts. NBER Working Paper 7701.

Broz, J. L., \& Hawes, M. B. (2006). US domestic politics and international monetary fund policy. In D. G. Hawkins, D. A. Lake, D. L. Nielson, \& M. J. Tierney (Eds), Delegation and Agency in International Organizations (pp. 77-106). Cambridge: Cambridge University Press.

Brune, N., Garrett, G., \& Kogut, B. (2004). The International Monetary Fund and the global spread of privatization. IMF Staff Papers, 51, 195-219.

Bulow, J., \& Rogoff, K. (1990). Cleaning up third world debt without getting taken to the cleaners. Journal of Economic Perspectives, 4, 31-42.

Butkiewicz, J. L., \& Yanikkaya, H. (2005). The effects of IMF and World Bank lending on long-run economic growth: An empirical analysis. World Development, 33, 371-391.

Chwieroth, J. (2007). Testing and measuring the role of ideas: The case of neoliberalism in the International Monetary Fund. International Studies Quarterly, 51, 5-30.

Cole, H. L., Dow, J., \& English, W. B. (1995). International Economic Review, 36, 365-385.

Copelovitch, M. S. (2005). Governing global markets: private debt and the politics of International Monetary Fund Lending. Ph.D. thesis, Harvard University.

Dicks-Mireaux, L., Mecagni, M., \& Schadler, S. (2000). Evaluating the effect of IMF lending to lowincome countries. Journal of Development Economics, 61, 495-526.

Dreher, A. (2003). The influence of elections on IMF programme interruptions. Journal of Development Studies, 39, 101-120.

Dreher, A. (2004). A public choice perspective of IMF and World Bank lending and conditionality. Public Choice, 119, 445-464.

Dreher, A. (2006). IMF and economic growth: The effects of programs, loans, and compliance with conditionality. World Development, 34, 769-788.

Dreher, A., \& Jensen, N. M. (2007). Independent actor of agent? An empirical analysis of the impact of US interests on IMF conditions. Journal of Law and Economics, 50(1), 1-22.

Dreher, A., \& Vaubel, R. (2004a). Do IMF and IBRD cause moral hazard and political business cycles? Evidence from panel data. Open Economies Review, 15, 5-22.

Dreher, A., \& Vaubel, R. (2004b). The causes and consequences of IMF conditionality. Emerging Markets Finance and Trade, 40, 26-54.

Easterly, W. (2001). The elusive quest for growth: Economists' adventures and misadventures in the tropics. Cambridge and London: MIT Press. 
Easterly, W. (2005). What did structural adjustment adjust? The association of policies and growth with repeated IMF and World Bank adjustment loans. Journal of Development Economics, 76, 1-22.

Easton, S. T., \& Rockerbie, D. W. (1999). What's in a default? Lending to LDCs in the face of default risk. Journal of Development Economics, 58, 319-332.

Edwards, M. S. (2005). Investor responses to IMF program suspensions: Is noncompliance costly?" Social Science Quarterly, 86, 857-873.

Eichengreen, B., Gupta, P. \& Mody, A. (2006). Sudden stops and IMF-supported programs. Cambridge, Mass.: NBER Working Paper.

Evrensel, A. Y. (2002). Effectiveness of IMF-supported stabilization programs in developing countries. Journal of International Money and Finance, 21, 565-587.

Garuda, G. (2000). The distributional effects of IMF Programs: A cross-country analysis. World Development, 28, 1031-1051.

Goldstein, M., \& Montiel, P. (1986). Evaluating fund stabilization programs with multi-country data: Some methodological pitfalls. IMF Staff Papers, 33, 304-344.

Goldstein, M. (1998). The Asian financial crisis: causes, cures and systemic implications. Institute for International Economic.

Goldstein, M. (2001). IMF structural conditionality: How much is too much? Institute for International Economics Working Paper 01-04.

Gould, E. R. (2003). Money talks: Supplementary financiers and International Monetary Fund conditionality. International Organization, 57, 551-586.

Gould, E. R. (2006). Money talks: The International Monetary Fund, conditionality, and supplementary financiers. Stanford: Stanford University Press.

Haggard, S., \& Kaufman, R. R. (1995). The political economy of democratic transitions. Princeton: Princeton University Press.

Heckman, J. J. (1979). Sample selection bias as a specification error. Econometrica, 47, 153-162.

Hills, C. A., Peterson, P. G., \& Goldstein, M. (1999). Safeguarding prosperity in a global financial system: The future international financial architecture. Washington, DC: Council on Foreign Relations and Institute for International Economics.

Hutchison, M. M. (2003). A cure worse than the disease? Currency crises and the output costs of IMFsupported stabilization programs. In M. P. Dooley \& F. A. Jeffrey (Eds.), Managing Currency Crises in Emerging Markets (pp 321-359) Chicago: University of Chicago Press.

IMF. (2002). What is the IMF? http://www.imf.org/external/pubs/ft/exrp/what.htm.

IEO. (2003a). Fiscal adjustment in IMF-supported programs. Washington, D.C.: Independent Evaluation Office, International Monetary Fund.

IEO. (2003b). The IMF and recent capital account crises: Indonesia, Korea, Brazil. Washington, D.C.: Independent Evaluation Office, International Monetary Fund.

IEO. (2004). The IMF and Argentina, 1991-2001. Washington, D.C.: Independent Evaluation Office, International Monetary Fund.

Ivanova, A., Wolfgang, M., Mourmouras, A., \& Anayiotos, G. (2003). What determines the implementation of IMF-supported programs? IMF Working Papers 03/8.

Jensen, N. M. (2004). Crisis, conditions, and capital: The effect of International Monetary Fund agreements on foreign direct investment inflows. Journal of Conflict Resolution, 48, 194-210.

Joyce, J. (2004). Adoption, implementation and impact of IMF programmes: A review of the issues and evidence. Comparative Economic Studies, 46, 451-457.

Joyce, J. P. (2006). Promises made, promises broken: A model of IMF program implementation. Economics \& Politics, 18, 339-365.

Keohane, R. O. (1984). After hegemony: Cooperation and discord in the world political economy. Princeton: Princeton Univ. Press.

Koremenos, B., Lipson, C., \& Snidal, D. (eds.) (2004). The rational design of international institutions. Cambridge: Cambridge University Press.

Krasner, S. D. (1985). Structural conflict: The third world against global liberalism. Berkeley: University of California Press.

Krueger, A. O. A response to Allan Meltzer. Review of international organizations, 1, 61-64.

Lee, J-W., \& Rhee, C. (2000). Macroeconomic impacts of the Korean financial crisis: Comparison with the cross-country patterns. Rochester Center for Economic Research Working Paper 471.

Lipson, C. (1985). Standing guard: Protecting foreign capital in the nineteenth and twentieth centuries. Berkeley: University of California Press.

Marchesi, S. (2003). Adoption of an IMF programme and debt rescheduling: An empirical analysis. Journal of Development Economics, 70(2), 403-423. 
Marchesi, S., \& Thomas, J. P. (1999). IMF conditionality as a screening device. Economic Journal, 109, 111-125.

Meltzer, A. H. (2000). International Financial Institution Advisory Commission (IFIAC or Meltzer Commission). Final Report. (March). http://www.house.gov/jec/imf/meltzer.pdf, (May 25, 2005).

Meltzer, A. H. (2006). Reviving the bank and the fund. Review of International Organizations, 1, 49-59.

Mody, A., \& Saravia, D. (2003). Catalyzing capital flows: Do IMF-supported programs work as commitment devices? IMF Working Papers 03/100.

Nooruddin, I., \& Simmons, J. W. (2006). The politics of hard choices: IMF programs and government spending. International Organization, 60, 1001-1033.

Nsouli, S. M., Atoian, R., \& Mourmouras, A. (2006). Institutions, program implementation, and macroeconomic performance. In A. Mody, \& Rebucci A. (Eds.), IMF Supported Programs: Recent Staff Research (pp. 140-159). Washington, D.C.: International Monetary Fund.

Oye, K. (1992). Economic discrimination and political exchange: World political economy in the 1930s and 1980s. Princeton: Princeton University Press.

Plaut, S. E., \& Melnik, A. L. (2003). International institutional lending arrangements to sovereign borrowers. Journal of International Money and Finance, 22, 459-481.

Powell, A., \& Arozamena, L. (2003). Liquidity protection versus moral hazard: The role of the IMF. Journal of International Money and Finance, 22, 1041-1063.

Poirier, D. J. (1980). Partial observability in bivariate probit models. Journal of Econometrics, 12, $210-217$.

Pop-Eleches, G. (2007). From economic crisis to reform: IMF programs in Latin America and Eastern Europe. Princeton: Princeton University Press (in press).

Przeworski, A., \& Vreeland, J. R. (2000). The Effect of IMF Programs on Economic Growth. Journal of Development Economics, 62, 385-421.

Przeworski, A., \& Vreeland, J. R. (2002). A statistical model of bilateral cooperation. Political Analysis, 10, 101-112.

Putnam, R. D. (1988). Diplomacy and domestic politics. International Organization, 42, 427-460.

Simmons, B. A. (2000a). International law and state behavior: Commitment and compliance in International Monetary Affairs. American Political Science Review, 94, 819-835.

Simmons, B. A. (2000b). The legalization of international monetary affairs. International Organization, $54(3), 573-602$.

Simmons, B. A., \& Hopkins, D. J. (2005). The constraining power of international treaties: Theory and methods. American Political Science Review, 99, 623-631.

Stiglitz, J. E. (2002). Globalization and its discontents. New York: W. W. Norton.

Stone, R. W. (2002). Lending credibility: The international monetary fund and the post-communist transition. Princeton: Princeton University Press.

Stone, R. W. (2004). The political economy of IMF lending in Africa. American Political Science Review, $98,577-591$.

Stone, R. W. (2008). The scope of IMF conditionality: How autonomous is the Fund? Manuscript, University of Rochester (in press).

Sturm, J-E., Berger, H., \& de Haan, J. (2005). Which variables explain decisions on IMF credit? An extreme bounds analysis. Economics and Politics, 17, 177-213.

Thacker, S. C. (1999). The high politics of IMF lending. World Politics, 52, 38-75.

Ukraine (1998). Memorandum of Economic Policies for July 1, 1998-June 30, 2001. Washington, D.C.: IMF, August 18, 1998. http://www.imf.org/external/np/loi/081198.htm.

Vaubel, R. (1986). A public choice approach to international organization. Public Choice, 51, 39-57.

Vaubel, R. (1991). The political economy of the International Monetary Fund: A public choice approach. In R. Vaubel, \& T. D. Willett (Eds.), The Political Economy of International Organizations (pp. 205245). Boulder: Westview.

Vaubel, R. (1996). Bureaucracy at the IMF and the World Bank: A comparison of the evidence. World Economy, 19, 195-210.

Von Stein, J. (2005). Do treaties constrain or screen? Selection bias and treaty compliance. American Political Science Review, 99, 611-622.

Vreeland, J. R. (2003). The IMF and economic development. Cambridge: Cambridge University Press.

Vreeland, J. R. (2003b). Why do governments and the IMF enter into agreements? Statistically selected cases. International Political Science Review, 24, 321-343.

Vreeland, J. R. (2006). IMF program compliance: Aggregate index versus policy specific research strategies. Review of International Organizations, 1, 359-378.

Wells, R. (1993). Tolerance of arrearages: How IMF loan policy can effect debt reduction. American Economic Review, 83, 621-633.

Williamson, J. (1997). The Washington consensus Revisited. In E. Louis (Ed.), Economic and Social Development into the XXI Century. Washington, D.C.: Inter-American Development Bank. 